\title{
Social Justice and Equity in the UK Education System
}

\author{
Yung-Ming Shu ${ }^{\mathrm{a}, *}$ and Ren-Jie Lin ${ }^{\mathrm{b},+}$ \\ ${ }^{a}$ National Tsing Hua University, Taiwan \\ ${ }^{\mathrm{b}}$ National Taiwan University of Sport, Taiwan
}

\begin{abstract}
This article is a review of educational justice in the United Kingdom. Historical roots are investigated. The main existing problems are: (1) the dual system, (2) the equality of university admissions, and (3) remedial education opportunities for disadvantaged pupils. There are recommendations from parliament and nongovernmental organizations, which are considered in this article. A summary of their suggestions include (1) reduce economic inequality, (2) eliminate the distinction between independent and state-funded schools, (3) promote adequate market mechanisms, and (4) offer more remedial education.
\end{abstract}

Keywords: Educational Justice, United Kingdom, School System, Equity, Equality

\section{Introduction}

It has never been easy to gauge the social justice in a nation's education system, which is a common topic for many researchers to determine. Therefore, attempts should (and will) be made, regardless of the difficulties to achieve this feat. According to Social Justice in the EU (2014), the UK eventually ranked 13th among $28 \mathrm{EU}$ countries by six indexes of social justice. This index report comprises six key indices: Poverty Prevention, Equitable Education, Labor Market Access, Social Cohesion and Nondiscrimination, Health, and Intergenerational Justice. Among these indices, the UK ranked 17th in Equitable Education (Schraad-Tischer and Kroll 2014, p. 27).

The EU report evaluated equitable education using four indicators, namely education policy, impact of socioeconomic factors on educational performance, pre-primary education expenditures, and early school leavers. The first indicator was based on qualitative data and provided no ranking; the second was made according to the Programme for International Pupil Assessment (PISA), for which the UK ranked 11th; and on the second and third indicators, the UK ranked 26th and 22nd, respectively (Schraad-Tischer and Kroll 2014, pp. 3, 18, 34, and 36). However, we argue that this social justice assessment of the UK remains comprehensively inade-

*Corresponding author email: ymshu@mx.nthu.edu.tw; †Corresponding author email: vincentlin@ntupes.edu.tw. quate. Hence, the present study investigated what other indicators could be deemed suitable for the subject, and an assessment was formulated accordingly.

Although there have been a substantial number of reports and assessments on education and social justice in the UK, this study examined the education system from a holistic viewpoint, encompassing both macro and micro perspectives. Methodologically, we relied primarily on an extensive literature review that ranged from an examination of all aspects of the education system (including government and nongovernmental reports) to formal assessments on social justice.

\section{Assessment Standards}

Regarding social justice in the education system, this study integrated perspectives from Rawls' theory of justice and Nussbaum's and Sen's capability approach as follows (Nussbaum 2011, p. 14; Rawls 1971, p. 91; Sen 1993, pp. 30-53):

1. First, from the perspective of needs, if education is offered on the basis of students' intellectual capabilities, schools must invest more resources in gifted individuals and people with disabilities or other disadvantages. This is justified in two ways: first, beyond adaptive development, society would receive more cost-effective benefits by investing in gifted in- 
dividuals; second, people with disabilities or other disadvantages require more resources than people without such disadvantages to develop the potentials that sustain their basic survival.

2. Everyone can infinitely expand their claim of needs; therefore, investments in gifted individuals must be determined by their actual contributions, while investments in people with disabilities or other disadvantages should be geared towards developing their abilities for basic living.

3. These views make necessary adjustments to the aforementioned theories. For instance, the possible infinite exaggeration of needs is curbed. Rawls' difference principle is served because the disadvantaged also benefit from it. And the development of basic survival abilities among people with disadvantages fulfils the capacity approach (and addresses this aspect that is not covered by Rawls' theory of justice).

Thus, social justice in the education system can be defined as follows. First, all students should be allowed to develop to their full potential, regardless of gender, ethnicity, social hierarchy, or region of origin (adaptive development). Additionally, these aspects can intertwine or overlap with each other. Second, every country should offer a basic and compulsory national education for every citizen; beyond that lies the continual education for adaptive development. Third, the education system of a society should also offer an equal start to everyone. Specifically, disadvantaged people should be compensated before entering school, rather than simply being treated equally at school. Fourth, both gifted individuals and people who experience disadvantages should receive appropriate interventions and preparation before entering school. Fifth, the equality of admission, course of education, and accessibility of continual education after graduation should all be taken into consideration. Sixth, social mobility is an excellent overall indicator. Thus, social movements promoted by different social groups on gender, ethnicity and social hierarchy topics should be encouraged; otherwise, an unfair society forms because impenetrable social barriers make the weak always weak and the strong always strong. Finally, the elimination of all forms of unfairness is passive action, whereas positive discrimination (i.e., allocating more compensation to the disadvantaged) is active action.

From the preceding rationale, the present study used social mobility at all levels of the UK society as a conclusive indicator; this is similar to Sutton Trust's motto of "improving social mobility through education." (Sutton Trust 1994, p. 3) We also examined process indicators by exploring the historic background of the education system and assessing admission equality and the flexibility to transfer between schools of the same level. Additionally, the accessibility of compensatory education for disadvantaged people was also deemed a key indicator of the assessment.

\section{Social Mobility in the Contemporary UK Society}

According to Elitist Britain, published by the Social Mobility and Child Poverty Commission (2014a), there is a significant demarcation between receiving secondary education at state-funded schools and independent schools. Of all students in the eligible age group, 7 percent attend aristocratic independent schools, 4 percent attend grammar schools, and 88 percent attend comprehensive schools. However, this distribution is not reflected in the population of Oxford and Cambridge ("Oxbridge") university students. Specifically, 7 percent of independent school students comprise as high as 49 percent of Oxbridge students, whereas students from other schools compete for the remaining 51 percent. Moreover, although the alumni of Oxbridge constitute less than 1 percent of the total UK population, they are disproportionally overrepresented in high paying and powerful jobs nationwide.

The overrepresentation of independent school graduates in these jobs is starkly evident in the following statistics:

Senior judges (71\%), Senior armed forces officers (62\%), Commons Select Committee Chairs (57\%), Permanent Secretaries (55\%), Diplomats (53\%), Lords (50\%), Public body chairs (45\%), Sunday Times Rich List (44\%), TV, film and music (44\%), Newspaper columnists (43\%), Radio 4 influential women (42\%), Cabinet (36\%), Public body CEOs (34\%), MPs (33\%), Cricket - England (33\%), BBC executives (28\%), Chief Constables/Police \& Crime Commissioners (22\%), FTSE 350 CEOs (22\%), Pop stars (22\%), Shadow cabinet (22\%), University Vice-Chancellors (20\%), Local government leaders (15\%), Local government CEOs ( $8 \%$ ). (Social Mobility and Child Poverty Commission 2014a, pp. 12-13)

Among these influential positions, the numbers of independent school graduates as Members of Parliament have decreased over the years. Indeed, the figures provided here are the lowest overall compared with previous years, distinctly revealing the slow changes that are occurring in the UK society over time.

Moreover, these figures should cause an indignant outcry from the public over the unfairness of the current UK social strata. Despite the decreased dominance of the elite class (in terms of employment figures in powerful positions) over the years, overall improvement remains limited. Under the dual education system, the UK continues to repeat to existing social hierarchy that, although the 
government constantly vows to disrupt the status quo, there are no current signs of fundamental change.

\section{An Overview of the UK Education System}

\section{The Dual System}

Social hierarchy results from accumulated social development over several years, barring revolutionary effects. The UK is a nation that has spilled little blood in this regard, hence the deeply rooted and highly hierarchical system. Because the evolution of the education system is more susceptible to extrinsic influences than other systems, we selected six historical milestones to examine.

\section{The Elementary Education Act of 1870}

Social hierarchy has always been the primary determinant of the UK education system. Although the UK was the first industrialized country, compulsory education in the UK initially had a later start than both Germany (then Prussia) and France. The delay was mainly caused by opposition from the middle and upper classes, who were unwilling to have their children attend the same schools as the lower class. The Parliament was able to resist compulsory education until the Elementary Education Act (1870), which Green (1990, p. 33) noted was introduced to control the "skilled working class" who were enfranchised in 1867. However, although the Act was ostensibly passed to develop discipline, upper- and middleclass citizens continued to defy it by sending their children to independent schools instead of state-funded schools.

Previously, the Factory Act (1833) had only specified the amount of time per week child laborers should spend on education; moreover, the Newcastle Commission (1858) was against free elementary education and instead advocated for "payment by results," which determined a school's governmental grant allocation according to how satisfactorily students performed on examinations. In 1868, the Taunton Report proposed an education system built on the basis of social hierarchy. Finally, the Elementary Education Act was passed in 1870 and began the nation's compulsory education system. It is clear that the boycott of compulsory education by the privileged has occurred for centuries, manifesting today in the form of their attendance in independent schools.

\section{The Education Act of 1902}

The distinction between elementary and secondary schools in the UK was originally also the distinction between social classes: the lower class had no access to further education after elementary school, whereas the middle and upper classes would skip elementary school and directly enter secondary school after being tutored at home or attending preparatory schools set up by private secondary schools. In 1902, in an effort to bridge elementary and secondary education, the UK government established both higher grade elementary schools and free (albeit limited) secondary education opportunities. The Fisher Education Act of 1918 viewed the higher grade elementary schools as middle schools under the jurisdiction of Local Education Authorities (LEAs). However, although the middle schools resembled secondary schools in duration, they were essentially still elementary schools; this is yet another example of the embodiment of British social hierarchy in its education system (Lin 1983, p. 186).

The 1902 Balfour Education Act was an extraordinary breakthrough because up until that point, the lower class was only deemed fit for elementary education, through which they would learn basic knowledge and skills before entering the job market. Incidentally, elementary schools were named as such because what they taught was considered "elementary" or "essential" for the lower class to know; there was no need for them to be educated any further. Another notable feature of this Act was the establishment of the LEAs.

\section{The Education Act of 1944}

In 1920, the Labour Party advocated "Secondary Education for All" as one of its key policy statements. Later, the Hadow Report of 1926 recommended the establishment of five varied post-elementary education systems according to psychological theory, and the Spens Report of 1938 proposed an examination at the age of 11 (the 11-plus examination) to categorize students on the basis of their abilities and interests, and direct them to either grammar schools, modern schools, or technical schools. The Education Act of 1944 substantiated the coexistence of these three school types, as recommended by the Norwood Report, and further outlined their purposes. Grammar school was offered to students aged 11 to 18 who intended to attend university, modern school provided compulsory education to pupils aged 11 to 16 , and technical school was offered to students aged 11 to 18 who intended to seek employment after graduation. In effect, this tripartite system acknowledged the formidability of independent schools; instead, it created a countermeasure for those students who could not afford independent schools but still wished to enter university. However, grammar schools were so tightly regulated that only those with outstanding performances were able to enter it. This remains true today, where grammar school students constitute approximately 4 percent of all secondary school students. 


\section{The Comprehensive School Movement}

By 1964, the 11-plus examination had been abolished in favor of comprehensive schools, which was initiated by the LEAs. At that time, 120 of the 149 LEAs were considering reforming their secondary schools to comprehensive schools (Simon 1991, p. 274). Because the independent schools remained unaffected by this proposal, much of the resistance this proposal received came from state-funded schools, particularly grammar schools. The Newsom Report of 1963, which was entitled Half Our Future, examined the education for the age group of 13 to 16 and famously noted by the then Education Secretary Edward Boyle that "the essential point is that all children should have an equal opportunity of acquiring intelligence and developing their talents and abilities to the full" (HMSO 1963). This statement virtually spurned the prevailing fatalistic theories on the endowment of ability and embraced adaptive development as the goal for education (Simon 1991).

After the Labour Party came to power in 1965, the Secretary of State for Education and Science, Anthony Crosland, ordered the reform for comprehensive schools to occur. In his Circular 10/65 (Department of Education and Science 1965), Crosland defined the model for comprehensive schools, and forced the LEAs into submission by controlling funding. However, when the Conservative Party returned to power in 1970, it took a discouraging stance by allowing the schools to autonomously decide whether they would apply for a reform. Notably, the Secretary of State for Education and Science at that time was later Prime Minister, Margaret Thatcher, whose administration saw far more reformation applications than any of her successors' or predecessors' administration. In her memoir, she claimed that of the 3,600 applications, she rejected only 325 (9 percent) (Thatcher 1995, p. 171).

Although the comprehensive school movement was primarily promoted by the Labour Party, the party switched its focus to market mechanisms under the motto of "New Labour" following the 1997 election win and effectively abandoned their ideal for comprehensive schools (Chitty 2013). By contrast, the Conservative Party currently base their appeal on open competitions to enhance efficiency, reasoning that the performances of students will naturally improve as long as efficiency is improved.

\section{The Role of Public Schools}

Notably, the "public school" in British English is a highly misleading term that originally referred to real public sector schools for the poor (Chou 2008, p. 176), but eventually became an umbrella term for aristocratic independent schools. Nevertheless, there is no doubt that they are a form of secondary schools, because their students enroll at the age of thirteen and stay on until they enter university.
Some of the public schools have their own preparatory schools, but these are not considered part of their parent public school; furthermore, preparatory school students must still pass the common entrance examination to be admitted.

Public schools have always been notorious for charging outrageously high tuition, perhaps in part because they do not receive any government funding. According to the Education Act of 1944, their status as independent schools is only granted if they do not benefit from government subsidization. Combining this status with the protection from powerful alumni, these schools are virtually untouchable despite wholly embodying social injustice.

\section{The Expansion of Academy Schools}

State-funded and privately run "academy" schools appeared in 2002, and by 2014 their numbers had grown from 3 to 3,980. According to statistics from January 2015, 3,381 of these academies were secondary schools, constituting 61.4 percent of state-funded secondary schools nationwide and the mainstream of the UK secondary education (Shen 2016). This trend was initiated by the Labour Party in 1997, although it was essentially a continuation of the Conservative Party's policies. In 2000, then-Secretary of State for Education and Skills, David Blunkett, announced his decision to establish "city academies" to "improve pupil performance and break the cycle of low expectations." This city academy program was inspired by the "city technology colleges" of the Conservative Party, as well as the charter schools in the United States (Shen 2016).

The popularity of academy schools has accelerated since 2010, following the passage of the Academies Act by the Conservatives and Liberal Democrats coalition government that same year. In May 2015, the Conservative Party again returned to power and the Department for Education (DfE) immediately announced its intention to more actively assist unsuccessful schools. The Education and Adoption Bill of 2015 was announced in June that same year and indicated that all "failing schools" would be converted to academies while "coasting schools" would be placed under surveillance to face the possibility of being forcibly converted into academies or having their headmasters replaced (DfE 2016a). The Education and Adoption Act was officially ratified on 22 March 2016, several days after the DfE publicized its Educational Excellence Everywhere white paper. This policy announced plans to convert all secondary and primary schools to academies by 2020, regardless of the current success of the schools (DfE 2016b). 


\section{The Equality of University Admission}

Although compulsory education in the UK ends in secondary education at the age of 16, the accessibility of university education is nevertheless a critical indicator for equality. According to Milburn (2012, p. 13), who compared the popularity of higher education among the upper, middle, and lower classes in the US, Australian, and UK societies, the UK upper class has the highest percentage of people who received higher education. He added that the percentage of people from the three socioeconomic classes attending a Russell Group university are 25 percent, 5 percent, and 3 percent, respectively. Furthermore, if the most privileged of households (20 percent) were compared with the least privileged of households (40 percent), attendance at highly selective universities among the most privileged would be seven times higher than the least privileged (Milburn 2012, p. 21). Additionally, of the students who attend Oxbridge, only $1 / 2,000$ received free school meals while in a statefunded school; this is in contrast to $1 / 20$ students who graduated from independent schools (Milburn 2012, p. 21). Millburn (2012, p. 22) concluded that approximately 2,000 state-funded schools produced the same number of graduates who would then be admitted by Oxbridge as those from just four independent secondary schools and one college.

According to the State of the Nation 2014: Social Mobility and Child Poverty in Great Britain (Social Mobility and Child Poverty Commission 2014b), 60 percent of students from impoverished households are unable to obtain the General Certificate of Secondary Education (GCSE); moreover, the number of struggling students from such households is four times that of those with satisfactory academic performances. Therefore, reducing the gap in academic performances between the wealthy and the impoverished has been deemed an urgent task. Among the key recommendations the report proposed that "Universities to use the removal of the student numbers cap to significantly close the access gap so that by 2020 they are aiming to admit 5,000 more students from a free school meals background, with Russell Group universities aiming to admit 3,000 more state-school students and 1,400 more working-class students who have the grades but currently do not get the places." Presently, 40 percent of students in secondary school plan to pursue higher education, and the percentage of such students from impoverished households rose to 12 percent in 2012. However, the current ratio of wealthy to impoverished university students is still dramatic at $6: 1$; it is clear that considerable work needs to be done to reach the Commission's 2020 goal (Social Mobility and Child Poverty Commission 2014b).

To ensure the accessibility of university education to students from middle- and low-income households or disadvantaged backgrounds, the Office for Fair Access (OFFA) was established as an independent nongovernmental public body with two major missions. The first is to collect tuition charging standards and access agreements from each university in the UK, and the second is to effectively provide more resources to help students from disadvantaged backgrounds receive higher education. The OFFA has implemented several policies to meet these missions, some of which require universities to offer more bursaries and scholarships, set up more awards and allowances, assist in seeking work opportunities, and assist students applying for student loans (OFFA 2016).

Additionally, OFFA is also a part of the Regulatory Partnership Group, which was established in September 2011 in response to the government's intention to gradually increase university tuition for UK students. On 6 November 2015, the Department for Business, Innovation and Skill (BIS), which is in charge of higher education in the UK, released a green paper that was subsequently been turned into a white paper in May 2016, entitled Success as a Knowledge Economy: Teaching Excellence, Social Mobility and Pupil Choice (BIS 2016). In the sections addressing social mobility, however, the report disclosed that the OFFA will be abolished, and its operations and functions will be merged with the Higher Education Funding Council for England to form a new agency called the Office for Students (OfS).

Furthermore, regarding the strategic plans for increasing university attendance among students from disadvantaged backgrounds and other underrepresented groups, the white paper reasserted the Prime Minister's goal of improving social mobility through education, particularly regarding the following two aims:

The Prime Minister has set two specific, clear goals for this area of higher education: to double the proportion of people from disadvantaged backgrounds entering university in 2020 compared to 2009 , and to increase the number of BME students going to university by $20 \%$ by 2020 . (BIS 2016, p. 32)

Here, the term BME (Black and Minority Ethnic) reflects the latest definition for disadvantaged groups.

Meanwhile, the UK government has also supported the Universities UK organization in the establishment of the Social Mobility Advisory Group, which aims to lead universities in formulating effective strategies to improve admission opportunities. One such strategy of note is the "name blind" application, which helps prevent ethnic and gender discrimination (BIS 2016, p. 55).

\section{Remedial Education for Disadvantaged Students}

Students in need of remedial education in the UK are primarily lower-middle class white Britons, immigrants from former colonies, and children of the mass of workers and refugees who recently 
migrated from Eastern Europe and the Middle East (Lin 2016). The current status of remedial education is discussed in the Unseen Children: Access and Achievement 20 Years On: Evidence Report, which was released by the Office for Standards in Education, Children's Services, and Skills (Ofsted) in 2013 (Ofsted 2013a).

The report describes a large-scale long-term investigation on the academic performance of impoverished children in England that was initiated by the Ofsted in 1993. A follow-up investigation was conducted 10 years later in 2003, with the purpose of determining whether the education policies had improved the academic performance of students from the lower-middle class and identifying shortcomings in education policies and environments amidst a swell of criticism (Ofsted 2013a). The 2013 report revealed the results of a third investigation, which was conducted to identify causes and solutions for the unsatisfactory academic performance of students from the lower-middle class, based on a 20 -year research period. Some specific suggestions included:

1. Supervision by the Ofsted should be conducted more thoroughly and frequently, particularly in the towns and villages of coastal, rural, and sparsely populated areas.

2. Central agencies must make the importance of improving attendance rates and academic performances clear to schools in the aforementioned remote areas.

3. Education policies should be more thoroughly implemented with the help of educational organizations, such as the National Leaders of Education.

4. National Service Teachers who receive governmental scholarships should be assigned to resource-poor or remote areas to account for the shortage or high turnover rate of local teachers.

Another essential measure suggests reducing the number of the NEETs, which usually refers to youth aged 16-24 who are "Not in Employment, Education, or Training." The term originated in the UK, but quickly spread worldwide. In its 2013 report, the Ofsted also urged local governments in England to work closely with local schools and communities to monitor school dropouts. Notably, this practice was proposed as early as 2010 by the Ofsted in its Children Missing from Education report, which determined that most dropouts came from impoverished lower-middle class households (Ofsted 2013b).

Among the social problems faced by such dropouts, the most serious has been criminal activity. According to quarterly statistics from the DfE, the number of NEETs in England between October and December of 2012 was estimated to be around 45,000, which was a significant decrease from the previous year's estimate during those same months. Moreover, a longitudinal analysis of the statistics gathered by the Quarterly Labour Force Survey between 2000 and 2013 indicated that the number of NEETs during the OctoberDecember period was at its lowest point in 13 years in 2013 (DfE 2013a).

The DfE has noted that in the forthcoming Educational Excellence Everywhere white paper, a "Parent Portal" will be added to facilitate more convenient reviews of schools and their performances for parents, through the performance tables website (DfE 2016 b, p. 66). Although the sole aim of the white paper is educational excellence, such a measure will also benefit disadvantaged students.

\section{Suggestions for the UK Education System}

Inequality in UK society is a widely recognized fact. Although Parliament attempts to mitigate it by passing new laws and a large number of civic foundations have been diligently monitoring the problem, limited headway has been made. Although all of the parties involved have recognized education as a key factor, and have proposed specific reformative measures, they have been unable to influence the powers at work behind the scenes. Here, we discuss the problem from the following five angles.

\section{The Social Justice in the EU Report}

The Social Justice in the EU Report has the following remarks on the UK's overall efforts to pursue social justice:

The recent improvements in the UK with respect to the "relationship between socioeconomic background and educational performance" indicators are interesting. It remains too early to be able to assess whether the reforms implemented here in recent years will show a lasting effect. In their current report, the SGI country experts offer a nuanced view of policy successes and continuing challenges: "The coalition has continued to pursue the marketization started by its New Labour predecessors in education. It has liberalized the school sector to enable nongovernmental organizations such as foundations, businesses, parent-and-teacher corporations, etc. to find their own schools. This has been contentious within the coalition, however. The core approach of education policy is to improve performance by boosting inter-school competition, mainly through performance tables administered by the regulator Ofsted. Programs like the Pupil Premium are designed to encourage good schools to accept disadvantaged children and thus improve education while strengthening social cohesion. However, the socioeconomic composition of many of the country's schools still poses 
a significant challenge for disadvantaged students and those with an immigrant background. Cuts in the education budget (by 5.7 percent in 2012) and re-allocations have further added to the problems of the sector. The UK-more accurately England, as Scotland, Wales and Northern Ireland have different systems - still has a pronounced divide between those who opt for private education (confusingly, known as public school) and those who go through the state system. There is a concern about pupils leaving school with no qualifications, and occasional alarms about certain segments of the youth population doing significantly worse than others. Exam results for late secondary pupils have been improving, but there has been an accusation that marking standards have slipped, leading the current education minister to push for tougher, more discriminating standards. Other debates concern the exercise of control by local authorities over the school system, with some attempt to weaken it, as mentioned above. In the higher education sector, the drastic increase of tuition fees (from L3,300 to between L6,000 and L9,000 per annum) has been highly contentious. The effect on student enrollment cannot yet be assessed, although previous steps to push more of the costs of higher education from the general taxpayer to the student do not appear to have inhibited access for students from poorer backgrounds." (SchraadTischer and Kroll 2014, pp. 37-38)

In short, the report raised concern about the potential negative impact to social justice from the marketization of education policies. Although such a notion is still controversial, the negative impact has generally been accepted as a reality; similar conclusions can be observed from other reports.

\section{The Social Mobility Manifesto of Sutton Trust}

Sutton Trust (2014) advocates "improving social mobility through education," and has identified ten recommendations to improve social mobility in the UK:

1. Ensure all disadvantaged children can access the best earlyyear education and care. In particular, all disadvantaged twoyear-olds should have access to nursery places with wellqualified staff.

2. Make improving the quality of classroom teaching the top priority in schools, with effective appraisals and a guaranteed entitlement to good quality training for all teachers.

3. Create fairer school admissions to both state grammar schools and comprehensives at age 11, including through the increased use of ballots and banding in admissions.

4. Improve the impact of the pupil premiums through greater use of evidence provided by the Education Endowment Foundation and incentives for schools that narrow the attainment gap.

5. Develop an effective national program for highly-able state school pupils, with ring-fenced funding to support evidencebased activities and tracking of pupils' progress.

6. Strengthen academies' support for low- and middle-income pupils by regular inspection of chains, publication of more data across chains, and speedier interventions where academies are not working.

7. Break down barriers between state and private schools, by promoting more partnership working and opening 100 leading independent day schools to all on the basis of ability rather than ability to pay.

8. Provide every young person with an entitlement to good quality personalized education and careers guidance, strengthening the national careers service to support schools and colleges effectively.

9. Introduce a new body, separate from individual universities, for the effective coordination of evidence-based outreach programs, backed by more use of contextual admissions to improve access.

10. Greatly expand the number of good apprenticeships so that young people have real options at 18 and employers can develop the skilled workforce they need. (Sutton Trust 2014, p. 3)

Although these recommendations are comprehensive by nature, they are closely related to secondary education and cover virtually all the improvements necessary for every step in secondary education, from admission to learning to graduation.

\section{Will we ever have a fair education for all? The Fair Education Foundation Alliance Report Card}

The Fair Education Alliance is comprised of 25 charity groups, schools, labor unions, and commercial organizations. It assesses educational inequality in the UK annually through five indicators, in an attempt to complete the education system reform by 2022; in particular, the Fair Education Alliance is concerned with reducing the gap between the academic performances of the wealthy and the impoverished. The five impact goals are:

1. Narrow the gap in literacy and numeracy at primary school;

2. Narrow the gap in GCSE attainment at secondary school;

3 . Ensure young people develop key strengths, including resilience and wellbeing, to support high aspirations;

4. Narrow the gap in the proportion of young people taking part 
in further education or employment-based training after finishing their GCSEs; and

5. Narrow the gap in university graduation, including from the 25\% selective universities. (Fair Education Alliance 2014)

Notably, the GCSE described in points 2 and 4 above must be obtained by passing the examination at the end of secondary education, which is also the gateway to higher education. Thus, specific measures have to be taken to improve performance in this regard.

\section{State of the Nation 2014: Social Mobility and Child Poverty in Great Britain}

This report is a review of the status quo required by the Child Poverty Act (2010). Of the 12 suggestions it proposed, eight were directly education-oriented:

1. New focus in the early years on ensuring that children are school-ready at age five, with 85 per cent of children five, with 85 per cent of children - including three quarters of the poorest children - school-ready by 2020 and all by 2025 ;

2. A national parenting campaign to be launched to help more parents become excellent parents, funded by removing childcare tax breaks from families where at least one parent earns more than $£ 100,000$ per year;

3. Higher pay to get the best teachers into the worst schools in deprived areas of the county through a new Teachers' Pay Premium and new pay grades commissioned from the Teachers Pay Review Body;

4. Ending illiteracy and innumeracy among primary school leavers by 2025 and a new focus on quality careers advice, character development and extra-curricular activity in secondary schools;

5. Closing the attainment gap between poorer and better-off children to be a priority for all schools so that by 2020 more than half of children entitled to free school meals are achieving five good GCSEs rising to two-thirds by 2025;

6. Long-term youth unemployment to be ended by 2020 through a package of measures including half of all larger workplaces providing apprenticeships and a new Day One support service to help unemployed young people get straight back into work or education;

7. Universities to use the removal of the student numbers cap to significantly close the access gap so that by 2020 they are aiming to admit 5,000 more students from a free school meals background, with Russell Group universities aiming to admit 3,000 more state-school students and 1,400 more working- class students who have the grades but currently do not get the places; and

8. Unpaid internships to be ended - through legislation if necessary-by 2020. (Social Mobility and Child Poverty Commission 2014b, p. xiii)

Particularly critical is point 7 , which addresses the relatively low admission rate of top universities (i.e., Russell Group universities) for students from disadvantaged backgrounds, especially those who "have the grades but currently do not get the places." Current understanding for the gap is that it results from familial reasons.

\section{How fair is Britain? Equality, Health, Rights and Good Relations in 2010}

The Equality Act (2006) demands that periodical reports on the improvement of equality be sent to Parliament. In the How fair is Britain? Equality, Health, Rights, and Good Relations in 2010 Report, equality in the spectrums of life, legal security, physical security, health, education, employment, standard of living, care and support, and power and voice were assessed and the following eight indicators for equality in education were identified:

1. Level of development at age 5;

2. Permanent exclusion from school;

3. Bullying, respect and support at school;

4. Educational attainment at age 16;

5. Participation in higher education;

6. Adult skills and qualifications;

7. Adult learning; and

8. Use of the internet. (Equality and Human Rights Commission 2011, p. 302)

Notably, educational attainment at age 16 is directly related to secondary education, because it affects the accessibility of higher education. For many people, it is also the starting point for entering the workforce. Therefore, it is a crucial indicator for social equality.

In 2015, a new report released: Is Britain Fairer? In education, there are still five challenges to be solved. First, some persistent and in some cases widening educational attainment gaps (for example, among Gypsy and Traveller pupils, children from poorer backgrounds and particularly White boys, children with special educational needs and children in the care system); within the context of an overall fall, higher exclusion rates exist for some children (for example, children with special educational needs). 
Second, higher rates of bullying is carried out against some children (for example, disabled children and lesbian, gay and bisexual children). Third, there is generally lower participation of disabled young people in education, employment, and training. Fourth, women were more likely to have no qualifications than men, in contrast with the situation in higher education, where women more than closed the gap with men. And fifth, while more Black pupils in England went on to study at a higher education institution, they were less likely than Whites, mixed, and Asian pupils to go to higher-ranked institutions (Equality and $\mathrm{Hu}-$ man Rights Commission 2015, p. 3). It means that these old problems, mainly the disadvantaged groups are still need more help.

In summary, from a macro perspective, the most essential measures for social justice are to eliminate the distinction between independent- and state-funded schools and to eradicate inequality from the process of receiving education, including the rules for admission. However, other measures should also be taken into consideration because they also improve equality in various regards.

\section{General Suggestions}

In this section, we offer four general suggestions to help strengthen social justice in the UK education system.

\section{Reduce Economic Inequality}

Education is often the dependent variable of social transition, and many types of inequality find their roots in the gap between the educational achievements of the wealthy and the poor. According to the Office for National Statistics, Britain's richest 1 percent have accumulated as much wealth as the poorest 55 percent of the population put together (ONS 2016). Even after the Labour Party came to power in 1997, the gap remained high and increased (Lawton 2005, p. 158), which highlights how difficult the pursuit of social justice can be. As long as this pathogen exists, there can be no remedy for the problem without radical measures.

\section{Eliminate the Distinction between Independent- and State- funded Schools}

In the UK, the distinction between independent- and statefunded schools, in many ways reflects the distinction between aristocrats and commoners. This is primarily because the tuition charged by independent schools deters most poor- and averageearning people. Although it has been widely argued that admission should be ability-focused rather than wealth-focused, the connec- tion to wealth has yet to be removed because any attack on aristocratic independent schools is muted by the substantial power of their alumni; consequently, not only do independent schools not come under attack, but they grow even more formidable. Despite the obvious mockery of democracy and a marked source of inequality they represent, the prospect of abolishing them is politically impossible (Lawton 2005, p. 162). Indeed, several high-profile and established political figures have emerged from such schools, including many former Prime Ministers. Notably, however, the new Prime Minister, Theresa May (2016), lobbied to prevent state-funded grammar schools from becoming independent schools. She wanted to promote grammar school which is compatible with the elitist policy of the Conservative Party. But according to a recent research study, grammar school is not beneficial for social mobility (Andrews and Hutchinson 2016).

\section{Promote Adequate Market Mechanisms}

Market mechanisms have been among the primary routes of education reform since first being implemented by Margaret Thatcher in 1988. These mechanisms were reinforced by the New Labour Party in 1997. Later, the Conservative and Liberal Democrat coalition government in 2010 and 2016 the Conservatives solely are even more loyal adherers of this practice. During these time periods, more than half of the secondary schools were converted to academy schools to be run by corporations. Given that education contains elements of both public and private goods, excessive privatization of education is overwhelmingly detrimental to the pursuit of social justice.

\section{Offer More Remedial Education}

Margaret Archer (1979) used the concepts of centralization and decentralization to analyze education reform, and pointed out that in a decentralized setting, education reforms initiated by the central government would mostly focus on protecting the disadvantaged, because other groups are in possession of resources that enable them to achieve their goals on their own through external transactions (see also Sue 2014). In other words, the privileged can satisfy their needs through external transactions (e.g., setting up independent schools), whereas people who experience various disadvantages can be almost entirely dependent on governmental subsidies or charity groups. The UK has for a long time been a predominantly decentralized country. However, it has increasingly centralized in education policy since Thatcher served as Prime Minister. Most of the white papers released by the UK government have only focused on the pursuit of excellence or meritocracy, which is of limited help in the face of the immediate survival concerns of disadvantaged 
people. We suggest that the most active approach to enhance education equality is to provide remedial education to disadvantaged peoples. Although the UK government has been working towards implementing such policies, the measures for positive discrimination have always been half-hearted and the compensations rendered piecemeal.

\section{Conclusion}

This study investigated education equality in the UK. Examining the historical factors of inequality revealed that a dual education system has always existed in the nation. Moreover, inequality in university admissions remains stark, and the enrollment of students from disadvantaged backgrounds remains low. Strategies for improvement, such as remedial education, are positive but require substantial upgrading from their current iteration. According to the suggestions proposed by various groups, we suggested four directions for future efforts: (1) reducing economic inequality, (2) eliminating the distinction between independent- and state-funded schools, (3) reexamining the adequacy of market mechanisms, and (4) improving remedial education for people facing various disadvantages. Nevertheless, each of these four directions is challenging.

\section{References}

Andrews, Jon, and Jo Hutchinson. 2016. Grammar Schools and Social Mobility. London: Education Policy Institute.

Archer, Margaret. 2013. Social Origins of Educational Systems. London: Routledge.

Benn, Caroline, and Clyde Chitty. 1997. Thirty Years On: Is Comprehensive Education Alive and Well or Struggling to Survive? London: Penguin Books.

Department for Business, Innovation and Skills (BIS). 2015. "Fulfilling Our Potential: Teaching Excellence, Social Mobility and Pupil Choice." Available online: http://www.gov.uk/government/uploads/system/uploads/attachment_data/file/472227/BIS15-623-fullfilling-our-potential-teaching-excellenc-social-mobility-and-pupil-choice.pdf; accessed 20 April 2015.

BIS. 2016. "Success as a Knowledge Economy: Teaching Excellence, Social Mobility and Pupil Choice." Available online: https:/www.gov.uk/government/uploads/system/uploads/attachment data/file/523546/bis-16-265-success-as-a-knowledge-economy-web.pdf; accessed 26 May 2016.

Chan, Ying. 2016. "Teaching Excellence Framework: New Plans for Educational Evaluation Mechanisms of UK Universities." Evaluation Bimonthly 62. Available online: http://epaper.heeact.edu.tw/archive/2016/07/01/6580.aspx; accessed 27 July 2016.
Chitty, Clyde. 2013. New Labour and Secondary Education, 19942010. New York: Palgrave.

Chou, Yu-Wen. 2008. History of British Education: Modern Times (1780-1944). Taipei, Taiwan: Pro-Ed Publishing Company.

Department of Education and Science. 1965. "Circular 10/65: To Local Education Authorities and the Governors of Direct Grant, Voluntary Aided and Special Agreement Schools." Available online: http://www.educationengland.org.uk/documents/des/circular10-65.html; accessed 20 March 2016.

Department for Education (DfE). 2013. Summer Schools Programme for Disadvantaged Pupils: Overview Report. London: DfE.

DfE. 2016a. Education and Adoption Act 2016. London: DfE. Available online: http://services.parliament.uk/bills/2015-16/educationandadoption.html; accessed 20 March 2016.

DfE. 2016b. Educational Excellence Everywhere. London: DfE. Available online: http://www.nationalarchives.gov.uk/doc/opengovernment-licence/version/3; accessed 27 July 2016.

Equality and Human Rights Commission. 2011. "How Fair is Britain? Equality, Health, Rights and Good Relations in 2010." Available online: http://www.equalityhumanrights.com/sites/default/files/documents/triennial_review/how fair is britain - complete report.pdf; accessed 3 March 2015.

Equality and Human Rights Commission. 2015. "Is Britain Fairer? The State of Equality and Human Rights 2015.” Available online: https://assets.publishing.service.gov.uk/government/uploads/system/uploads/attachment data/file/476333/EHRC IBF MainReport acc.pdf; accessed 4 September 2018

Fair Education Alliance. 2014. "Will We ever Have a Fair Education for All?" Available online: http://static1.squarespace.com/static/543e665de4b0fbb2b140b2 91/t/5481a731e4b0d2f5ad3b39fb/1417783096688/FEA+Report+Card+2014.pdf; accessed 8 April 2015.

Green, Andy. 1990. Education and State Formation: The Rise of Education Systems in England, France and the USA. London: Macmillan Press.

Her Majesty's Stationery Office. 1963. "Half of Our Future.” Available online: http://www.educationengland.org.uk/documents/newsom; accessed 5 June 2015.

Lin, Ching-Jiang. 1983. Comparative Education. Taipei, Taiwan: Wunan Culture Enterprise.

Lin, Ren-Jie. 2016. "A Study of Remedial Teaching Policies in the UK." Journal of Educational Research 267: 83-98.

May, Teresa. 2016. "Britain, the Great Meritocracy." Available online: https:/www.gov.uk/government/speeches/britain-the-greatmeritocracy-prime-ministers-speech; accessed 22 September 2016.

Milburn, Alan. 2012. "University Challenge: How Higher Education Can Advance Social Mobility.” London: Social Mobility 
and Child Poverty Commission. Available online: https://www.gov.uk/government/uploads/system/uploads/attachment_data/file/80188/Higher-Education.pdf; accessed 17 November 2016.

Nussbaum, Martha. 2011. Creating Capabilities: The Human Development Approach. London: The Belknap Press of Harvard University Press.

Office for Fair Access. 2010. "What More Can Be Done to Widen Access to Highly Selective Universities?" Available online: https://www.offa.org.uk/wp-content/uploads/2010/05/Reporton-access-to-highly-selective-universities.pdf; accessed 28 November 2016.

Office for Standards in Education, Children's Services and Skills (Ofsted). 2013a. Unseen Children: Access and Achievement 20 Years on Evidence Report. Manchester, UK: Ofsted.

Ofsted. 2013b. Children Missing from Education. Manchester, UK: Ofsted.

Office for National Statistics. 2016. "Britain's Richest 1\% Own as Much as Poorest 55\% of Population." Available online: https://www.theguardian.com/uk-news/2014/may/15/britainsrichest-1-percent-own-same-as-bottom-55-population; accessed 16 November 2016.

Rawls, John. 1971. A Theory of Justice. Oxford, UK: Oxford University Press.

Schraad-Tischer, Daniel, and Christian Kroll. 2014. "Social Justice in the EU-A Cross-National Comparison: Social Inclusion Monitor Europe (SIM) - Index Report." Available online: http://www.sginetwork.org/docs/2014/basics/Social_Justice in the EU_2014.pdf; accessed 5 December 2014.

Shen, San-San. 2010. "Access to Higher Education in England: The Factors of Competence and Equity." Bulletin of Educational Resources and Research 48: 139-158.

Shen, San-San. 2013. "The Secondary School Admission System in the UK: The Implications for the National Twelve-Year Basic Education System in Taiwan." Bulletin of Educational Resources and Research 58: 43-70.

Shen, San-San. 2016. "Social Justice in the Transformation of Secondary Schools in the UK." In Equality of Educational Opportunity, edited by Ming-Li Wen, 67-92. New Taipei City: National Academy for Educational Research.

Shu, Yung-Ming. 2014. “Implications of Archer's Morphogenesis in the Educational Development in Various Countries." In Comparative and International Education, edited by Shen-Keng Yang, Chiou-Rong Wang Yang, and Feng-Jih Lee (pp. 755782). Taipei, Taiwan: Edu-book.

Simon, Brian. 1991. Educational and the Social Order: British Education Since 1944. London: Lawrence and Wishart.
Social Mobility and Child Poverty Commission. 2014a. "Elitist Britain.” Available online: https://www.gov.uk/government/uploads/system/uploads/attachment_data/file/347915/Elitist_Britain _Final.pdf; accessed 18 April 2015.

Social Mobility and Child Poverty Commission. 2014b. "State of the Nation 2014: Social Mobility and Child Poverty in Great Britain." Available online: https://www.gov.uk/government/uploads/system/uploads/attachment data/file/365765/State of Nation 2014_Main_Report.pdf; accessed 15 February 2015.

Sutton Trust. 2014. "Social Mobility Manifesto." Available online: http://www.suttontrust.com/wp-content/uploads/2014/09/MobilityManifesto-2015.pdf; accessed 2 April 2015.

Thatcher, Margaret. 1995. Margaret Thatcher: The Path to Power. New York: HarperCollins Publishers. 